\title{
Fisheries impacts on lake ecosystem structure in the context of a changing climate and trophic state
}

\author{
Tiina NÕGES,,${ }^{1 *}$ Orlane ANNEVILLE,,${ }^{2}$ Jean GUILLARD,${ }^{2}$ Juta HABERMAN,${ }^{1}$ Ain JÄRVALT, ${ }^{1}$ Marina MANCA, ${ }^{3}$ \\ Giuseppe MORABITO, ${ }^{3}$ Michela ROGORA, ${ }^{3}$ Stephen J. THACKERAY, ${ }^{4}$ Pietro VOLTA, ${ }^{3}$ Ian J. WINFIELD, ${ }^{4}$ \\ Peeter NÕGES ${ }^{1}$
}

${ }^{1}$ Centre for Limnology, Institute of Agricultural and Environmental Research, Estonian University of Life Sciences, Rannu 61117, Tartu County, Estonia; ${ }^{2}$ CARRTEL, INRA, Université Savoie Mont Blanc, 75 Avenue de Corzent, 74200 Thonon les Bains, France; ${ }^{3}$ CNR Institute of Ecosystem Study, Largo Tonolli 50, 28922 Verbania Pallanza, Italy; ${ }^{4}$ Lake Ecosystems Group, Centre for Ecology \& Hydrology, Lancaster Environment Centre, Library Avenue, Bailrigg, Lancaster, LA1 4AP, UK Corresponding author: Tiina.Noges@emu.ee

\begin{abstract}
Through cascading effects within lake food webs, commercial and recreational fisheries may indirectly affect the abundances of organisms at lower trophic levels, such as phytoplankton, even if they are not directly consumed. So far, interactive effects of fisheries, changing trophic state and climate upon lake ecosystems have been largely overlooked. Here we analyse case studies from five European lake basins of differing trophic states (Lake Võrtsjärv, two basins of Windermere, Lake Geneva and Lake Maggiore) with long-term limnological and fisheries data. Decreasing phosphorus concentrations (re-oligotrophication) and increasing water temperatures have been reported in all five lake basins, while phytoplankton concentration has decreased only slightly or even increased in some cases. To examine possible ecosystem-scale effects of fisheries, we analysed correlations between fish and fisheries data, and other food web components and environmental factors. Re-oligotrophication over different ranges of the trophic scale induced different fish responses. In the deeper lakes Geneva and Maggiore, we found a stronger link between phytoplankton and planktivorous fish and thus a more important cascading top-down effect than in other lakes. This connection makes careful ecosystem-based fisheries management extremely important for maintaining high water quality in such systems. We also demonstrated that increasing water temperature might favour piscivores at low phosphorus loading, but suppresses them at high phosphorus loading and might thus either enhance or diminish the cascading top-down control over phytoplankton with strong implications for water quality.
\end{abstract}

Key words: Fish and fishery; lake; long-term changes; ecosystem impacts; ecosystem-based fisheries management.

Received: March 2017. Accepted: June 2017

\section{INTRODUCTION}

Changes in fish assemblages are commonly used to evaluate aquatic ecosystem stress because, with their relatively long lifespan, fishes integrate the effects of shortand long-term stressors (Dobiesz et al., 2010). Sustainable fisheries are critical for human welfare and biodiversity conservation, with overfishing posing numerous threats to the functioning of the whole ecosystem by triggering trophic cascades and altering food web dynamics (McIntyre et al., 2007; Salomon et al., 2008).

The socio-ecological significance of fisheries, and major stressors that impact them, differ between marine and freshwater ecosystems. Fishing is recognized as one of the most important ecosystem services provided by the world's oceans but, in addition to this, lakes provide a diversity of other ecosystem services as well, for example the provision of drinking water. Thus, lake management is primarily focused on maintaining high water quality which in turn facilitates the multiple services that lakes are expected to provide (Baron and Poff, 2004). In oceans, fish stocks suffer mainly from overfishing (Beddington et al., 2007), while in lakes a reduction in the abundance of commercially important fish is often caused by human activities such as eutrophication (Schindler, 2006; Alexander et al., 2017) in the lake or its catchment, rather than by intensive fishing. Although many studies have addressed the impact of lake fisheries management on fish stocks (Pine et al., 2009; Cowx and Portocarrero, 2011; Everson et al., 2013; Kolding and van Zwieten, 2014; Persson et al., 2014; Suuronen and Bartley, 2014; Fraker et al., 2015; Anneville et al., 2015; DuFour et al., 2015), the variability in lake fish communities is still mostly related to changes in environmental pressures such as eutrophication (Vonlanthen et al., 2012) or species introductions (Trochine et al., 2017). As a consequence, lake management practices focus on pollution control, habitat conservation and/or manipulation in order to enhance ecosystem health and assure the availability of all ecosystem services including professional and recreational fishing. 
Both marine and freshwater ecosystems are driven by subtle and complex combinations of bottom-up and topdown controls which in turn are influenced by food web structure and composition (Gallardo et al., 2016). In addition, because food web structure and composition are sensitive to climate change and other environmental disturbances, there is also a need to consider and understand not only the interactions among and between species but also those with their environment. From the early 2000s, Ecosystem-Based Fisheries Management (EBFM), which originated in the marine realm and which incorporates a holistic approach as its basic tenet, has gained increasingly popularity around the world. As noted by Pikitch et al. (2004), EBFM represents a new direction for fishery management and essentially reverses the order of management priorities to start with the ecosystem rather than with the target species, with the overall objective to sustain healthy ecosystems and the fisheries they support.

Since the 1980s (Shapiro and Wright, 1984; Carpenter et al., 1985), detailed food web studies have recognized that cascading effects in lakes are particularly visible because aquatic organisms are characterized by strong trophic links which can be profoundly disturbed by changes in biodiversity. As an example, Gallardo et al. (2016) underlined the impact of invasive fish predators on different trophic levels of aquatic ecosystems. Because of strong cascading trophic interactions in lakes, Shapiro and Wright (1984) proposed using fish for lake restoration by either removing planktivorous fish directly or by introducing or favouring the growth of piscivorous fish. Both measures should favour zooplankton development and enable it to control efficiently phytoplankton biomass. This method, "biomanipulation", (Shapiro and Wright, 1984) has been implemented in many lakes to improve water quality. Biomanipulation has been extensively applied in the lakes of north-western Europe, most of all in Denmark and the Netherlands and both successful (e.g., lakes IJzeren Man and Nannewijd) and unsuccessful (e.g., lakes Klein Vogelenzang, Geerplas) experiences have been reported (Søndergaard et al., 2007). As concluded by Gulati et al. (2008), the positive effects of biomanipulation have been sustained for over a decade in less than half of all cases.

While top-down cascades from fish to phytoplankton have been a core topic in recent limnology, they have attracted far less interest in marine ecology because lake studies have been largely aimed at regulating eutrophication-induced algal blooms while marine studies have been more oriented towards fish yield (Hessen and Kaartvedt, 2014). However, there are still fewer directly EBFMaligned studies in lakes compared to in marine systems, and in both environments the cascading effects of fisheries on the whole ecosystem are only rarely addressed due to their data-demanding nature. Nevertheless, because fish- ing can drive large-scale ecosystem changes, fisheries management should target the recovery of entire ecosystems to more desirable and resilient states. The partial recovery of fish stocks only is not a stable objective, because a further change in another component of the ecosystem (e.g., in climate or alien species) may drive the system into another catastrophic loop (Daskalov et al., 2007). Understanding the relative importance of top-down and bottom-up mechanisms in regulating ecosystem structure is a fundamental ecological question with implications for both fisheries and water-quality management. Accordingly, a recent study in the Laurentian Great Lakes underlined the importance of continued monitoring to extend time series, and of mechanistic research to test correlative findings, with the overall goal of enhancing the ability of managers to implement ecosystem-based management approaches (Bunnell et al., 2014).

The present study compiles and analyses long-term data from four European lakes, i.e. Lake Võrtsjärv, Windermere (with two basins), Lake Geneva and Lake Maggiore, which differ in trophic state and fishing pressure, to explore variation in the extent and strength of top-down cascading effects of fish and fisheries at the ecosystem level. In particular, we attempt to identify the potential driving factors that shape the community structure of these ecosystems by evaluating the effects of multiple stressors (e.g., nutrient loading, fishing pressure, and temperature) on the fisheries and food webs of these five lake basins.

\section{METHODS}

\section{Study sites}

We focus our study on four medium-to-large lakes for which long-term records of fisheries activity, and associated ecosystem variables, exist. The lakes were selected to represent a wide gradient in depth, trophic state and fisheries intensity (Fig. 1). The deepest and most oligotrophic lake, Maggiore, has experienced the strongest fishery pressure, followed by the shallowest and most eutrophic lake, Võrtsjärv. In both basins of Windermere, the fishing intensity was low.

\section{Lake Võrtsjärv}

Lake Võrtsjärv is a large and very shallow lowland lake in Estonia (Tab. 1) which has suffered from increasing nutrient loads from agriculture since the 1950s (Nõges and Nõges, 2012). Among our case study lakes, Võrtsjärv is the second largest by surface area and the most eutrophic (Tab. 1). Since 1961, surface water temperature has significantly increased in spring, summer and autumn, at rates of up to $0.39^{\circ} \mathrm{C}$ decade $^{-1}$ (for August, Nõges and Nõges, 2014). Thirty-one fish species and one lamprey species inhabit Võrtsjärv and its tributaries permanently. Eels 
(Anguilla anguilla (L.)) have been introduced to and stocked into Vorrtsjärv since 1956 and have become the most important commercial fish followed by pikeperch (Sander lucioperca (L.)), pike (Esox lucius L.) and bream (Abramis brama (L.)). Catches of roach (Rutilus rutilus (L.)), burbot (Lota lota (L.)) and perch (Perca fluviatilis L.) are also considerable. Ruffe (Gymnocephalus cernuus (L.)), bleak (Alburnus alburnus (L.)) and lake smelt (Osmerus eperlanus) have lost their commercial importance following prohibition of the use of fine meshed trawls since the 1970s (Järvalt et al., 2004). The lake has an in- tensive commercial fishery with well documented yearly catches for all commercial fish species since 1971, and at a lower resolution since 1935 (Nõges et al., 2016). In years when a severe winter coincides with a low water level, serious fish kills may occur (Nõges and Nõges, 2012).

\section{Windermere}

Windermere is a large and deep meso-eutrophic lake comprising elongated northern and southern basins. Both phosphorus concentration and phytoplankton abundance

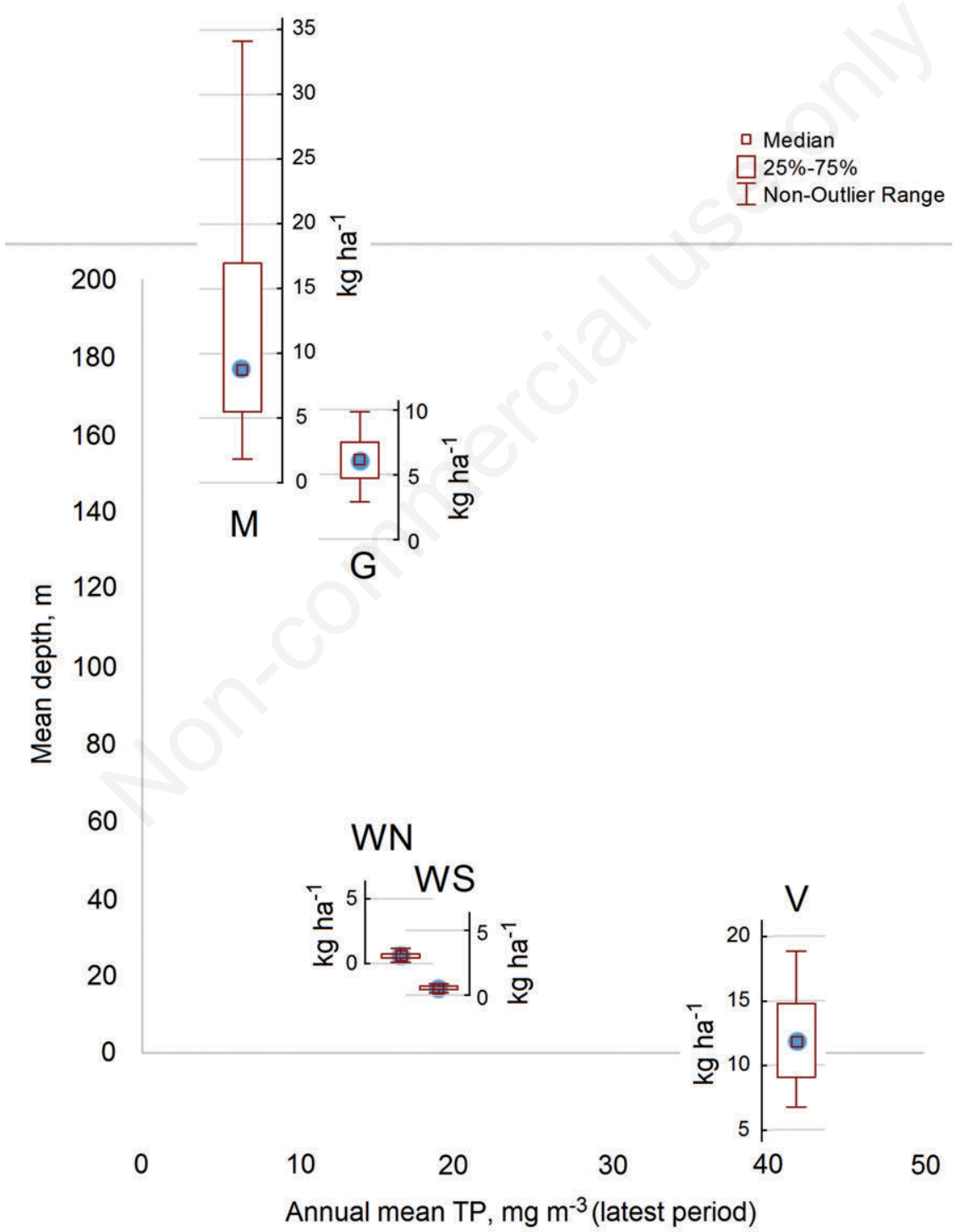

Fig. 1. Ecological gradients among the study lakes. The lake basins are plotted in a plane defined by their mean depth and annual mean total phosphorus concentration, with summaries of annual fish catches indicated by boxplots. The location of the median fish catch indicates the position of each lake basin in the TP - mean depth plane. The non-outlier range covers values that fall below the upper outlier limit ( $+1.5 *$ the height of the box) and above the lower outlier limit (-1.5* the height of the box). M, Maggiore; G, Geneva; WN, Windermere North Basin; WS, Windermere South Basin; V, Võrtsjärv. 
are consistently lower in the north than in the south basin (Tab. 1). The surface water temperature of Windermere has shown a significant increase since the late 1980s (Winfield et al., 2008a, 2008b). The fish community includes 16 species, although only Arctic charr (Salvelinus alpinus (L.)), perch, pike and, in recent years, introduced roach are abundant (Winfield et al., 2008a). Commercial fisheries have not operated for many decades, but a smallscale recreational fishery persists for Arctic charr and catch-and-release angling is practised for pike and some other species (Le Cren, 2001).

\section{Lake Geneva}

Lake Geneva, a deep peri-alpine lake located on the border between France and Switzerland is the largest in our study, in terms of surface area (Tab. 1). In the second half of the $20^{\text {th }}$ century, the lake experienced a rapid increase in nutrient concentrations which switched it from oligotrophy to eutrophy, with annual mean total phosphorus (TP) concentrations reaching $89 \mathrm{mg} / \mathrm{m}^{3}$ (Anneville and Pelletier, 2000), but these have now been lowered as a result of a reduction in phosphorus loadings (Tab. 1). Besides changes in trophic status, the effect of climate variability has become evident during the last few decades: the water temperature in the 0-20 m layer has increased markedly during winter and spring and though summer temperatures do not show any warming trend, they are strongly influenced by subtropical Atlantic climate variability (Molinero et al., 2007). In addition, the phytoplankton community has undergone an important shift in species composition (Anneville et al., 2002). Within the zooplankton community, Daphnia, one of the preferred prey items of zooplanktivorous fish, showed an overall decrease in abundance between 1986 and 2010 (Laine and Perga, 2015). Fish species caught by professional fishers have included Arctic charr, pike, burbot, roach, brown trout (Salmo trutta L.), perch and whitefish (Coregonus lavaretus (L.)). The contribution of whitefish to commercial catches decreased from $25 \%$ in $1950-1962$ to $10 \%$ in $1963-1978$. From 1979 to the mid-1990s, whitefish contribution remained low and catches were dominated by percids that made up $76 \%$ of the total catches ( $41 \%$ for perch and 35\% for roach). Since the 1990 s, whitefish contributions started to increase again (up to 66\% in 2010-2012) accompanied by a decrease in roach contributions while perch remained high ranging from $32 \%$ to $70 \%$ (Anneville et al., 2017).

\section{Lake Maggiore}

Lake Maggiore is a large holo-oligomictic and naturally oligotrophic lake (Marchetto et al., 2004); the deepest and most oligotrophic in our study (Tab. 1). In the late 1950s, TP in Maggiore began to rise and by the late 1970s, the lake reached a trophic state close to eutrophy with maximum TP concentrations of $30 \mathrm{mg} / \mathrm{m}^{3}$ during winter mixing. Since the 1980s, nutrient loads have been significantly reduced and in-lake TP in the whole water column has decreased to $10 \mathrm{mg} / \mathrm{m}^{3}$ (Manca and Ruggiu, 1998; Obertegger and Manca, 2011). Phytoplankton biomass gradually declined, with a time lag, following the reduction of nutrient loads (Fastner et al., 2016). The abundance of Daphnia longispina galeata gr. declined with lake re-oligotrophication, but began to increase again after 1996 (Manca et al., 2007). There are 22 native fish species in Lake Maggiore but the lake has experienced extensive intentional introductions of fish species. In the $19^{\text {th }}$ century, a fast growing coregonid form introduced from Lake Konstanz took the local name of "lavarello" (Berg and Grimaldi, 1965). After World War II, a slow growing coregonid form, C. macrophthalmus N. (locally called "bondella") was also introduced for commercial purposes from Lake Neuchatel and soon became a major target of the commercial fishery alongside bleak (Grimaldi and Numann, 1972). Since the 1990s, roach, ruffe, pikeperch, crucian carp (Carassius carassius (L.)), bitterling (Rhodeus amarus Bloch), and wels catfish (Silurus glanis L.) were introduced.

In recent decades, global warming has affected lake surface temperature as well the winter mixing, resulting in a gradual reduction of the depth reached by convective mixing (Ambrosetti et al., 2010).

Tab. 1. General characteristics of the case study lakes. Total phosphorus and chlorophyll $a(\mathrm{Chl} a)$ concentrations in the upper/mixed water columns are the mean values of the latest year of the time series presented in Fig. 5 and Tab. 3.

\begin{tabular}{|c|c|c|c|c|c|c|c|c|}
\hline Lake basin & Latitude & Longitude & $\begin{array}{l}\text { Altitude } \\
\text { (m asl) }\end{array}$ & $\begin{array}{c}\text { Lake area } \\
\qquad\left(\mathrm{km}^{2}\right)\end{array}$ & $\begin{array}{l}\text { Mean depth } \\
\text { (m) }\end{array}$ & $\begin{array}{l}\text { Max. depth } \\
\text { (m) }\end{array}$ & $\begin{array}{l}\text { Annual mean } \\
\left.\text { TP (mg m } \mathbf{m}^{-3}\right) \\
\text { Latest year }\end{array}$ & $\begin{array}{c}\text { May-Oct mean } \\
\text { Chl } a\left(\mathrm{mg} \mathrm{m}^{-3}\right) \\
\text { Latest year }\end{array}$ \\
\hline Võrtsjärv & $58^{\circ} 17^{\prime} \mathrm{N}$ & $26^{\circ} 02^{\prime} \mathrm{E}$ & 34 & 270 & 2.8 & 6 & 42 & 47 \\
\hline Windermere North Basin & $54^{\circ} 21^{\prime} \mathrm{N}$ & $2^{\circ} 56^{\prime} \mathrm{W}$ & 39 & 8.1 & 25.1 & 64 & 16.6 & 8.2 \\
\hline Windermere South Basin & $54^{\circ} 21^{\prime} \mathrm{N}$ & $2^{\circ} 56^{\prime} \mathrm{W}$ & 39 & 6.7 & 16.8 & 39 & 19 & 11.3 \\
\hline Geneva & $46^{\circ} 27^{\prime} \mathrm{N}$ & $6^{\circ} 32^{\prime} \mathrm{E}$ & 372 & 582 & 153 & 309 & 14 & 4.5 \\
\hline Maggiore & $46^{\circ} 5^{\prime} \mathrm{N}$ & $8^{\circ} 43^{\prime} \mathrm{E}$ & 193 & 212 & 177 & 370 & 6.4 & 2.4 \\
\hline
\end{tabular}

TP, total phosphorus. 


\section{Data collection}

\section{Lake Võrtsjärv}

The present analysis is based on yearly statistics of commercial fish catches from the period 1971-2013. During this period, passive fishing gear (fish traps and gill nets) was used and the intensity of fishing remained at a relatively constant level of 300-360 fyke nets and 300360 gill nets (the number of fyke and gill net licences per year, with fyke nets set in the ice-free period, and gill nets from September up to the next spring ice-out, usually in March). In addition, experimental trawling as a sampling method for fish stock monitoring was started in 1981. During the ice-free period (April-November), fish were caught with a bottom otter trawl (mouth width $8 \mathrm{~m}$, height $2.5 \mathrm{~m}$, cod-end mesh size $12 \mathrm{~mm}$ ). In the pelagic part of the lake 15-20 hauls per year, lasting 15 to 30 minutes each, were made in the daytime at a trawling speed of 4.5 $\mathrm{km} / \mathrm{h}$. Catch per unit effort (CPUE) of the trawl was calculated in kilograms per trawl-hour.

Water chemistry, phyto- and zooplankton have been studied since 1964, 1-4 times per month. A series of 1-litre samples was taken with a Ruttner sampler at 1-m intervals from the surface to the bottom and mixed in a tank. For phytoplankton, a subsample of $250 \mathrm{ml}$ was preserved with acidified Lugol's solution and analysed microscopically as described by Nõges et al. (2010). TP was analysed according to Grasshoff et al. (1983). Zooplankton samples were taken with a quantitative Juday net ( $85 \mu \mathrm{m}$ mesh size), towed from the bottom to the surface (in 1964-2000) or by filtering $20 \mathrm{~L}$ of depth-integrated water through a net of 48 $\mu \mathrm{m}$ mesh size (since 2001), preserved with acidified Lugol's solution and counted under a stereomicroscope Nikon (SMZ1500) in a Bogorov chamber at up to 120x magnification. For biomass calculations, the average body length of 10 individuals from each taxon was measured. The length of adult crustaceans was converted to weight according to Balushkina and Vinberg (1979). Water temperature was measured daily at the outflow and data were provided by the Estonian Meteorological and Hydrological Institute.

\section{Windermere}

In the absence of commercial fisheries, the Arctic charr, perch, pike and roach populations have been studied and annually monitored (with the exception of roach which only became numerous in the 1990s) since the early 1940s using a range of methodologies including gill nets targeted at Arctic charr (Winfield et al., 2008a), gill nets targeted at pike (Winfield et al., 2008b; Paxton et al., 2009) and traps targeted at perch (Paxton et al., 2004), augmented by the collection of Arctic charr recreational angling records since the mid-1960s (Winfield et al., 2008a) and the use of survey gill nets at 5-year intervals since 1995 targeted at roach (Winfield et al., 2008b). This scientific monitoring constitutes the only removal of fish from the lake, with the exception of insignificant numbers of Arctic charr and brown trout removed by recreational anglers. The present analysis is based primarily on basin-specific annual sampling effort, absolute catch by numbers and weight for perch and pike, together with derived numerical CPUE and biomass CPUE for perch and pike monitoring and annual angler numerical CPUE for Arctic charr.

These fish studies have been accompanied by more frequent, typically daily, weekly or fortnightly, monitoring of the lake's abiotic and biotic features including water level, water temperature and phosphorus concentrations (Winfield et al., 2008a). The present analysis is based primarily on annual mean inshore surface water temperature, together with basin-specific mean concentrations of TP and Chl $a$ during May to October of each year. TP and Chl $a$ concentrations were determined from integrated surface water samples collected using a weighted plastic tube according to Mackereth et al. (1978) and Talling (1974), respectively. Details of the methodology used to determine water temperature are given by Winfield et al. (2008a), those used for TP concentrations and Chl $a$ are given by Parker and Maberly (2000).

\section{Lake Geneva}

In Lake Geneva, some physical parameters started to be regularly monitored at the end of the 1950s and a standardized long-term monitoring of physical and chemical variables, as well as plankton communities, was launched in 1974. Sampling takes place 1 or 2 times per month in the middle of the lake at its deepest part. Sampling protocols and analytical methods for physical, chemical and plankton variables are described in CIPEL annual reports (http://www.cipel.org/documentation/publications-cipel/) and on the website dedicated to the Observatory of LAkes (OLA) (http://www6.inra.fr/soere-ola). Water temperature was measured at discrete depths with a thermometer until 1998, after which multiprobes were used (Sharma et al., 2015). Water for nutrient measurements was collected at discrete depths and TP concentrations were estimated according to a standardized protocol (AFNOR NF EN 1189, Monod et al., 1984). Water for estimating phytoplankton as Chl $a$ was sampled at discrete depths and filtered through a Whatman $\mathrm{GF} / \mathrm{C}$ filter $(47 \mathrm{~mm})$. The pigments were extracted with $90 \%(\mathrm{v} / \mathrm{v})$ acetone/water, the solution was filtered through a GF/C filter $(25 \mathrm{~mm})$ and $\mathrm{Chl} a$ concentration was measured by spectrophotometry (Strickland and Parsons, 1968). Zooplankton was sampled from a depth of $50 \mathrm{~m}$ to the surface using a $200 \mu \mathrm{m}$ mesh plankton net. Samples were preserved in a 5\% buffered formaldehyde solution. Zooplankton species were identified and individuals were enumerated in a $0.1 \mathrm{~mL}$ sedimented subsample using a dissecting microscope (Anneville et al., 2007). 
Fish abundance data used in this study include commercial landing statistics compiled annually by the cantonal fisheries agency in Switzerland and the Haute-Savoie's Direction Départementale des Territoires (DDT) in France. French and Swiss commercial landing data are available since 1950, data on the number of French professional fishers are available since 1979, and fishing activity has been recorded for the last few years. The fishing activity is thought to be fairly constant since the numbers of commercial fishing permits and nets were kept constant at least until 1988 (Gerdeaux, 1988; Gerdeaux et al., 2006). For recent years, CPUE values ( $\mathrm{kg} /$ fisherman) have been computed based on French fish statistics provided by the HauteSavoie's DDT. The available French data allowed CPUE computation per species (Anneville et al., 2017) for the period 1979-2012. As these CPUEs indicated significant correlations with the French catches $(\mathrm{P}<0.005)$, we assumed that French catches give a good indication of the abundance of the different targeted fish species from the whole lake. Therefore, French catches were used in this analysis as a proxy of fish abundance.

\section{Lake Maggiore}

Data on fish and fisheries in Lake Maggiore remained scattered until the end of the 1970s when the Italian-Swiss Commission for the Fishery (Commissione Italo-Svizzera per la Pesca - CISPP) was established under the International Commission for the Protection of Italian-Swiss waters (CIPAIS). Since then, the total annual catch for each species of commercial interest and the number of active commercial fishermen have been recorded annually (Volta et al., 2011). This enabled the calculation of CPUE both for the total catch and for the most important commercial species as the harvest divided by the number of fishers (tonnes/individual per year).

Water temperature has been measured (Sharma et al., 2015) and samples for TP analysis have been collected monthly since 1979 at the deepest point of the lake at 0 , $5,10,20,30,50,100,150,200,250,300$ and $360 \mathrm{~m}$ depth. TP was analysed by spectrophotometry, after mineralization of the samples, according to Valderrama (1981). Mean volume-weighted values were calculated for the epilimnion $(0-25 \mathrm{~m})$ and for the whole water column (0-360 m). Mean annual values were calculated as the average of 12 monthly values. Samples for Chl $a$ and phytoplankton analysis were collected as integrated water from 0-20 m layer. Chl $a$ was determined spectrophotometrically after 90\% acetone extraction (Lorenzen, 1967) until 2010, then a fluorimetric in vivo method was adopted using a bbe Fluoroprobe instrument. Between 2008 and 2010, when the two methods were compared, a strong correlation was found $(\mathrm{r}=0.9, \mathrm{n}=27, \mathrm{P}<0.0001$; Morabito, unpublished data). Phytoplankton samples were preserved in acidic Lugol's solution; algal cells were counted under a Zeiss Axiovert 10 microscope, following Lund et al. (1958). Zooplankton samples were collected monthly with two Clarke-Bumpus plankton samplers (126 and 76 $\mu \mathrm{m}$ mesh size), towed together at a constant speed of $c a$ $3 \mathrm{~km} / \mathrm{h}$, along integrated sinusoidal hauls from 0 to $50 \mathrm{me}-$ ters. The samples were preserved in ethanol and then transferred into $5 \%$ formaldehyde before being counted in a proper sample fraction, addressing taxa and developmental stages abundance.

\section{Prediction of fish standing stock}

To assess the impact of fishery activities on standing stocks, we first needed to estimate the fish biomass in each lake basin (i.e., our fish community response variable). To do this, we used an established relationship between areal fish biomass and TP concentration, derived from lake data spanning a similar TP concentration range to our focal lakes (Yurk and Ney, 1989). Based upon this, we used annual TP concentrations in upper/mixed layers (Fig. 1A) to predict fish biomass, thus:

$\log _{10}$ Fish $\left(\mathrm{kg} \mathrm{ha}^{-1}\right)=1.07+1.14 * \log _{10} \mathrm{TP}\left(\mathrm{mg} \mathrm{m}^{-3}\right) \quad$ (eq. 1$)$

Among our case study lakes, we had estimates of the total fish biomass only for Võrtsjärv, calculated from pelagic trawling (method described by Nõges et al., 2016). Based on this, TP-based fish biomass in Võrtsjärv exceeded the trawling-based fish biomass on average by a factor of 6 . Considering that pelagic trawling might underestimate the fish biomass in a large shallow lake with an extensive littoral area, we accept that TP-based fish biomass involves a large extent of uncertainty. However, in our study it was the only option to at least roughly estimate the fish biomass and assess the exploitation rate of the fish stock. If the predictions are indeed biased, the estimated exploitation rates would change but the relative differences between systems would be unaffected.

\section{Statistical analyses}

To assess the evidence for long-term changes in the state of the case study lakes, we applied eWater toolkit (http://www.toolkit.net.au/Tools/TREND, last accessed on 16 June 2016). We used Mann-Kendall tests to detect trends, and cumulative deviation tests to detect step changes in time series of our measured variables. The non-parametric Mann-Kendall test is commonly employed to detect monotonic trends in series of environmental data, climate data or hydrological data; and the cumulative deviation test finds temporal breakpoints based on the rescaled cumulative sum of the deviations from the mean (see details of these methods in Kundzewicz and Robson, 2004; Li et al., 2008).

Fish occupying different ecological niches and trophic 
positions are likely to respond differently to environmental pressures. Therefore, when examining correlations between measures of fish stocks and environmental parameters we distinguished between the main plankti/benthivorous (MPB) and main piscivorous (MPi) fish species for each case study lake. Pikeperch was considered the MPi and bream the MPB in Lake Vortsjärv; pike the MPi and perch the MPB in Windermere (as the body size of this species has generally been small in this lake over the study period (Craig et al., 2015) and its diet consequently dominated by non-fish prey (McCormack, 1970; Craig, 1978) even though some periods of cannibalism have been reported (Le Cren, 1992); pike the MPi and whitefish the MPB in Lake Geneva; pikeperch the MPi and coregonids the MPB in Lake Maggiore. To assess these correlations, we used non-parametric Spearman rank order correlation analysis (Statistica, ver. 12, StatSoft, Inc.).

\section{RESULTS}

\section{Multiple pressures related to fish communities}

\section{Fisheries pressure}

Mean fish standing stocks calculated from annual TP concentrations varied from $153 \mathrm{~kg} \mathrm{ha}^{-1}$ in Lake Maggiore up to1034 $\mathrm{kg} \mathrm{ha}^{-1}$ in Võrtsjärv (Tab. 2). In Lake Geneva and Windermere less than $1 \%$ of this theoretical standing stock was removed from the lake annually, while in Vortsjärv (1.4\%) and in Maggiore (7.9\%), the fishing pressure was 1-2 orders of magnitude greater (Tab. 2, Fig. 2).

\section{Environmental pressures}

Though subject to marked inter-annual variation, TP concentrations exhibited a long-term decrease in all case study lakes while $\mathrm{Chl} a$ concentrations decreased only

Tab. 2. Annual theoretical fish standing stocks calculated on the basis of annual average total phosphorus (TP) concentration in the upper/mixed water column (see Fig. 5A) from the relationship $\log _{10}$ Fish $\left(\mathrm{kg} \mathrm{ha}^{-1}\right)=1.07+1.14 * \log _{10} \mathrm{TP}\left(\mathrm{mg} \mathrm{m}^{-3}\right)$ published by Yurk and Ney (1989); annual catch values based on fishery statistics and \% of the annual catches from the calculated fish standing stocks in case study lakes in 1980-2011.

\begin{tabular}{|c|c|c|c|c|c|c|c|}
\hline & & Years & $\mathbf{n}$ & Mean & Minimum & Maximum & Std dev \\
\hline \multirow[t]{5}{*}{ Võrtsjärv } & Annual TP mg m & $1983-2014$ & 32 & 50 & 22 & 129 & 20 \\
\hline & Fish stock, kg ha ${ }^{-1}$ & $1983-2014$ & 32 & 1034 & 400 & 2993 & 475 \\
\hline & Fish stock, tonnes lake ${ }^{-1}$ & $1983-2014$ & 32 & 27,913 & 10,804 & 80,805 & 12,825 \\
\hline & Annual catch tonnes lake ${ }^{-1}$ & $1980-2011$ & 32 & 340 & 183 & 720 & 124 \\
\hline & Annual catch, $\%$ of stock & $1980-2011$ & 29 & 1.4 & 0.6 & 4.1 & 0.7 \\
\hline \multirow[t]{5}{*}{ Windermere NB } & Annual TP $\mathrm{mg} \mathrm{m}^{-3}$ & $1980-2012$ & 33 & 14 & 11 & 17 & 1.4 \\
\hline & Fish stock, kg ha ${ }^{-1}$ & $1980-2012$ & 32 & 229 & 180 & 287 & 25 \\
\hline & Fish stock, tonnes lake ${ }^{-1}$ & $1980-2012$ & 32 & 185 & 146 & 233 & 21 \\
\hline & Annual catch tonnes lake ${ }^{-1}$ & $1980-2012$ & 33 & 0.51 & 0.09 & 0.97 & 0.23 \\
\hline & Annual catch, $\%$ of stock & $1980-2012$ & 32 & 0.28 & 0.04 & 0.56 & 0.14 \\
\hline \multirow[t]{5}{*}{ Windermere SB } & Annual TP $\mathrm{mg} \mathrm{m}^{-3}$ & $1980-2012$ & 33 & 21 & 13 & 31 & 4 \\
\hline & Fish stock, kg ha ${ }^{-1}$ & $1980-2012$ & 33 & 383 & 225 & 592 & 82 \\
\hline & Fish stock, tonnes lake ${ }^{-1}$ & $1980-2012$ & 33 & 257 & 151 & 396 & 55 \\
\hline & Annual catch tonnes lake ${ }^{-1}$ & $1980-2012$ & 33 & 0.4 & 0.1 & 0.6 & 0.1 \\
\hline & Annual catch, $\%$ of stock & $1980-2012$ & 32 & 0.1 & 0.0 & 0.2 & 0.0 \\
\hline \multirow[t]{5}{*}{ Geneva } & Annual TP $\mathrm{mg} \mathrm{m}^{-3}$ & $1974-2011$ & 38 & 31 & 14 & 56 & 16 \\
\hline & Fish stock, kg ha ${ }^{-1}$ & $1974-2011$ & 32 & 504 & 235 & 1130 & 294 \\
\hline & Fish stock, tonnes lake ${ }^{-1}$ & $1974-2011$ & 32 & 293,103 & 136,888 & 657,512 & 171,362 \\
\hline & Annual catch tonnes lake ${ }^{-1}$ & $1980-2011$ & 32 & 363 & 169 & 708 & 126 \\
\hline & Annual catch, $\%$ of stock & $1980-2011$ & 32 & 0.17 & 0.03 & 0.51 & 0.12 \\
\hline \multirow[t]{5}{*}{ Maggiore } & Annual TP $\mathrm{mg} \mathrm{m}^{-3}$ & $1979-2014$ & 36 & 10 & 6 & 19 & 3 \\
\hline & Fish stock, kg ha ${ }^{-1}$ & $1979-2014$ & 32 & 153 & 93 & 284 & 46 \\
\hline & Fish stock, tonnes lake ${ }^{-1}$ & $1979-2014$ & 32 & 3241 & 1978 & 6022 & 977 \\
\hline & Annual catch tonnes lake ${ }^{-1}$ & $1980-2010$ & 31 & 265 & 39 & 723 & 197 \\
\hline & Annual catch, $\%$ of stock & $1980-2010$ & 31 & 7.9 & 1.3 & 25.2 & 5.2 \\
\hline
\end{tabular}


slightly (Geneva and Maggiore) or even increased (Võrtsjärv and Windermere) (Tab. 3). Increasing trends of water temperature have been recorded in all lakes.

In Lake Maggiore, phytoplankton biomass was significantly positively correlated with TP and negatively with the CPUE of main piscivore, while it was vice versa in Lake Geneva. MPB and MPi were positively correlated in Võrtsjärv and Geneva, not correlated in Windermere, and negatively correlated in Maggiore. In Windermere, Geneva and Maggiore, MPi was positively correlated with water temperature (WT). In Geneva MPB was positively correlated with WT and negatively with TP, while in Maggiore it was vice versa. Daphnia was significantly negatively correlated with Bphyto, MPi and MPB in Lake Geneva but not in the other lakes (Fig. 3).

Some correlations showed regular changes along gra- dients of mean depth, TP, and Chl $a$ (Fig. 4). For example, the correlation between phytoplankton and MPB was strong and positive in deeper lakes with lower TP concentration (Geneva and Maggiore) but negative and weak in shallower lakes with higher TP concentration (Võrtsjärv and Windermere). The correlation between water temperature and MPi was positive in lakes with low and moderate TP and chlorophyll $a$ concentration but turned negative in Võrtsjärv characterised by high TP and Chl $a$.

\section{DISCUSSION}

\section{Factors controlling fish communities}

Among our case study lakes, Geneva and Maggiore have undergone drastic reductions in nutrient loading and
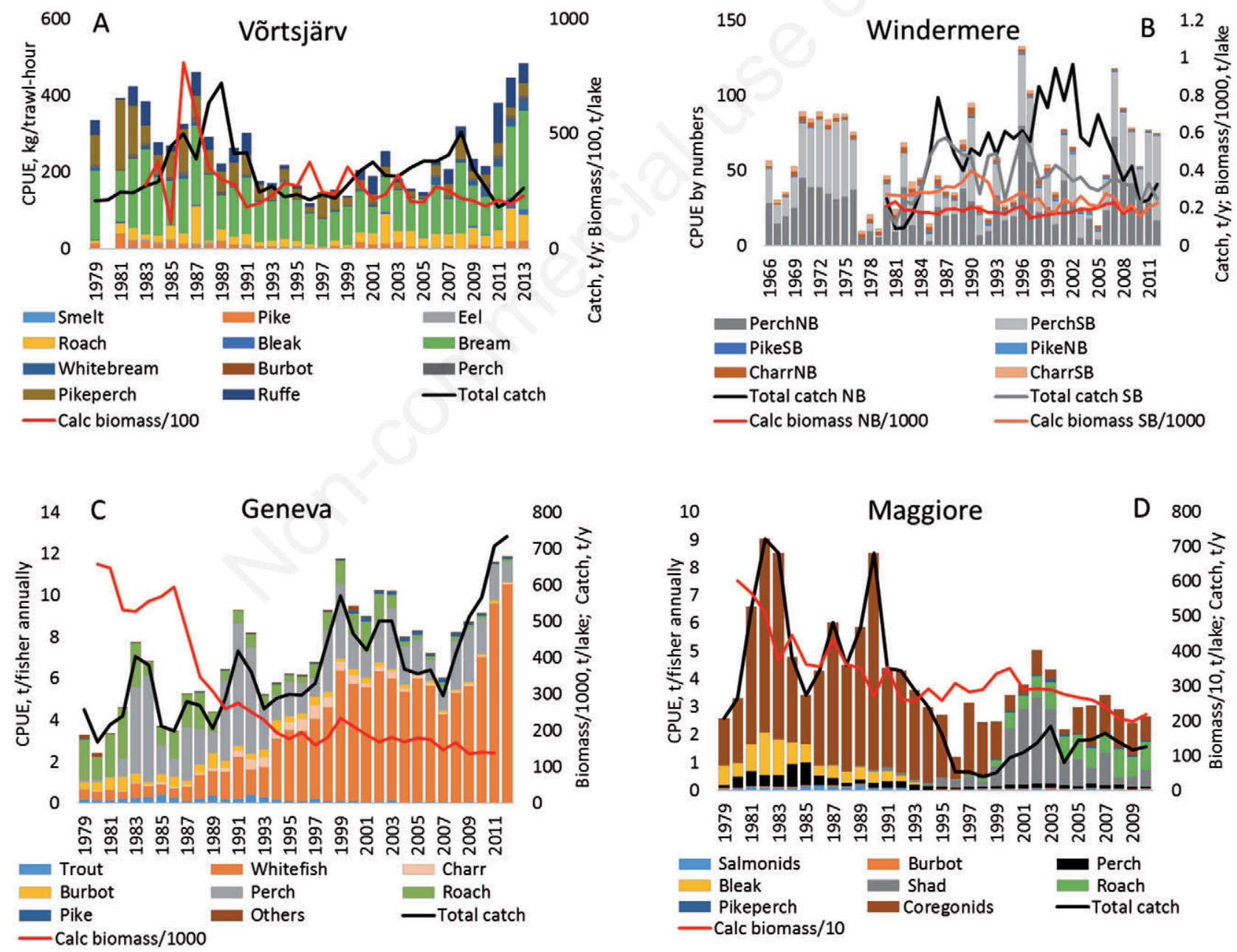

Fig. 2. Catch per unit effort (CPUE) by fish species, calculated fish biomass based on total phosphorus (TP) concentration (see Tab. 2) and total catch data in Lake Võrtsjärv in 1979-2013 (A); CPUE by fish species, calculated fish biomass based on TP in Windermere in 1966-2012; NB, North Basin; SB, South Basin (B); CPUE by fish species, calculated fish biomass based on TP and total catch data in Lake Geneva in 1979-2012 (C) and CPUE by fish species (Salmonids = trout + Arctic charr; Coregonids = lavarello + bondella), calculated fish biomass based on TP and total catch data) in Lake Maggiore in 1979-2010 (D); t, metric tonnes. 
considerable changes in fish communities. During this reoligotrophication, the total fish CPUE and especially that of coregonids has substantially increased in Lake Geneva (Gerdeaux et al., 2006) but decreased in Maggiore (Volta, 2000). It must be noted, however, that the "starting point"

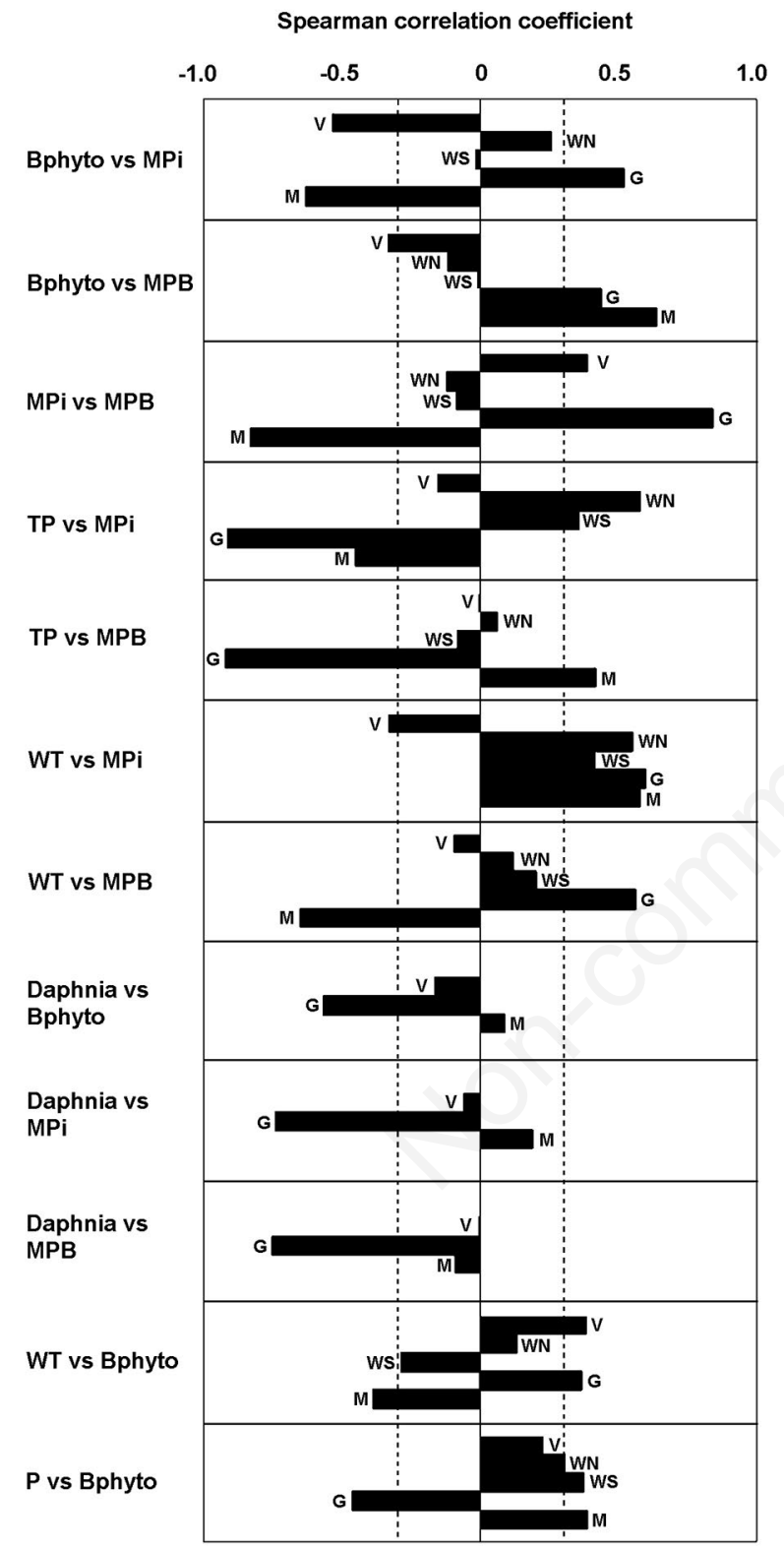

Fig. 3. Spearman correlation coefficients of fish feeding groups (catch per unit effort of main piscivorous (MPi) and main plankti/benthivorous (MPB) fish species; see explanation in text) with phytoplankton biomass (Bphyto), Daphnia, total phosphorus (TP) and water temperature (WT) in case study lakes Vorrtsjärv (V), Windermere North Basin (WN), Windermere South Basin (WS), Geneva (G), and Maggiore (M). Dashed lines denote the significance level at $\mathrm{P}=0.05$. of the re-oligotrophication trend was much higher in Lake Geneva where TP values have only now reached those from which Lake Maggiore started to decline at the end of the 1970s. Hence, these contrasting nutrient ranges may be the reason for the observed different responses of fish communities through food web interactions and differences in reproductive success and survival (Massol et al., 2007).

In Lake Geneva, the decrease in TP concentration was accompanied by a decrease in roach and perch an increase in whitefish CPUE (Gerdeaux, 2004; Anneville et al., 2017), thus the observed switch from percid and cyprinid to coregonid dominated community could have been induced by a change in the lake's trophic status (Jeppesen et al., 2005). However, changes in species contributions to commercial landings may also reflect changes in the habits of fishers. While the decrease in the contribution of perch to landings suggests a decrease in its abundance due to re-oligotrophication (Dubois et al., 2013), the contrasting fishery values of perch and roach and their consequently differing target profiles may complicate interpretation of the observed trends in catches. It seems that the trends in roach and perch follow from re-oligotrophication, because perch should have retained its commercial value.

The increase in whitefish abundances in Lake Geneva correlated strongly with decreasing TP concentration and increasing temperature (Fig. 3). Re-oligotrophication potentially increases reproductive success by re-oxygenation of spawning areas, improving egg survival which is strongly influenced by oxygen concentrations at the water-sediment interface (Müller, 1992). Warmer spring temperatures allow whitefish larvae to grow faster, and provide a better temporal match with the seasonal development of their prey species (Anneville et al., 2009). In addition, a change in the age structure of the whitefish population in the 2000 s also probably contributed to the increase in the population (Anneville et al., 2017). Because of the high fishing pressure, the whitefish cohort entering the stock used to be completely harvested (Caranhac and Gerdeaux, 1998). Before the 2000s, catches were made up of only few cohorts, mainly age $2+$ or $3+$, while fishes older than 4 years were rare in the lake. In contrast, recent studies have shown that fish caught by French fishers in recent years are older (Anneville et al., 2017). Such a change in the age structure of the catches indicates a high level of recruitment and that the stock is not entirely harvested anymore. The non-harvested brood stock now survive to spawn for several years and thus can contribute to the expansion of the stock. In Lake Geneva, the percentage of the calculated fish standing stock caught annually was one of the lowest among our case study lakes $(0.17 \%)$ and this could explain the continuously increasing fish biomass (CPUE) in this lake (Anneville et al., 2017). However, phosphorus concentration alone is 
apparently insufficient to estimate fish stock as the field data indicate that the relationship between phosphorus and fish is not so simple. In Lake Geneva, for example, low phosphorus concentrations are associated with high annual catches dominated by coregonid species (whitefish) which are sensitive to trophic status and whose reproductive success is impaired by eutrophic conditions. So, depending on fish community composition, the model may or may not be appropriate. Furthermore, the model makes the expected and general prediction that eutrophic lakes are more productive for fish than are oligotrophic lakes. However, in the range of TP variations observed in our case study lakes, parameters other than phosphorus such as pressure from fisheries and the balance between predatory and non-predatory fish may explain a considerable part of the observed variability in fish abundance. However, as the present study does not quantify the relative variance explained by these factors, it will be posed as a hypothesis for a further more sophisticated analysis.

In Lake Maggiore, the pressures affecting the coregonid population were rather different. The two deeper lakes considered in this study differ in their "trophic history", with Maggiore switching from mesotrophy to oligotrophy and Geneva from eutrophy to mesotrophy. In contrast to Geneva, the change in coregonid harvest in Maggiore was positively correlated with increasing TP concentration and negatively correlated with epilimnion temperature (Fig. 3), but, according to Massol et al. (2007), data from both lakes suggest that coregonids show highest catches at intermediate TP concentrations (15-30 $\left.\mu \mathrm{g} \mathrm{L}^{-1}\right)$. Among our case study lakes, the highest percentage of the calculated fish standing stock was caught annually in Maggiore (up to $25 \%$, exceeding other lakes by 1-2 orders of magnitude) (Tab. 2). We acknowledge that the fish biomass values calculated from TP concentrations are only crude estimates. However, even with this uncertainty it is still clear that the fishing pressure in Maggiore has been much stronger than in the other lakes. Although re-oligotrophication and the introduction of several fish species have undoubtedly had a strong impact on Lake Maggiore ecosystem, the high fishing pressure is likely to be among the reasons explaining the strong reduction in coregonids, trout and perch CPUE and is thus regarded as an important factor controlling the fish community in this lake.

Strong impacts of fisheries management measures on fish community composition and the balance between predatory and non-predatory fish species have been demonstrated in Võrtsjärv, where the banning of smallmeshed fishing gear in the 1970 s caused a major change in the age and size structure of fishes and contributed to the establishment of predatory fish control over previously dominant ruffe and roach populations (Nõges et al., 2016). This is consistent with the number of fyke nets and gill nets presently used, that indicate only a moderate fishing pressure. Neither of the fish feeding groups' abundances were correlated with Daphnia or TP and only

Tab. 3. Time series lengths, upward $(\uparrow)$ and downward $(\downarrow)$ trends and breakpoints, and mean concentrations of total phosphorus (TP) and chlorophyll a (Chl a) in the upper/mixed water layer of the case study lakes. Average values of TP and Chl a were calculated for the entire period, as well as before and after any temporal breakpoints detected.

\begin{tabular}{|c|c|c|c|c|c|c|}
\hline Lake. water laver & $\begin{array}{l}\text { Time } \\
\text { series } \\
\text { length }\end{array}$ & $\begin{array}{l}\text { Mann-Kendall } \\
\text { trend }\end{array}$ & $\begin{array}{l}\text { Breaknoint bv } \\
\text { Cumulative } \\
\text { deviation test }\end{array}$ & $\begin{array}{l}\text { Average } \\
\text { before } \\
\text { breakpoint }\end{array}$ & $\begin{array}{l}\text { Average } \\
\text { after } \\
\text { breakpoint }\end{array}$ & $\begin{array}{c}\text { Average } \\
\text { for } \\
\text { whole period }\end{array}$ \\
\hline & Annual TP & Annual TP & Annual TP & $\begin{array}{c}\text { Annual TP } \\
\left(\mathrm{mg} \mathrm{m}^{-3}\right)\end{array}$ & $\begin{array}{c}\text { Annual TP } \\
\left(\mathrm{mg} \mathrm{m}^{-3}\right)\end{array}$ & $\begin{array}{c}\text { Annual TP } \\
\left(\mathrm{mg} \mathrm{m}^{-3}\right)\end{array}$ \\
\hline Võrtsjärv, 0-3 m & $1983-2014$ & $\downarrow \mathrm{P}<0.01$ & $\downarrow 1990, \mathrm{P}<0.1$ & 67 & 45 & 50 \\
\hline Windermere NB, 0-7 m & $1980-2012$ & No & No & & & 14 \\
\hline Windermere SB, 0-7 m & $1980-2013$ & $\downarrow \mathrm{P}<0.01$ & $\downarrow 1992, \mathrm{P}<0.01$ & 25 & 19 & 21 \\
\hline Geneva, $0-20 \mathrm{~m}$ & $1974-2011$ & $\downarrow \mathrm{P}<0.01$ & $\downarrow 1988, \mathrm{P}<0.01$ & 49 & 19 & 31 \\
\hline \multirow[t]{2}{*}{ Maggiore, $0-25 \mathrm{~m}$} & $1979-2014$ & $\downarrow \mathrm{P}<0.01$ & $\downarrow 1989, \mathrm{P}<0.01$ & 13 & 8 & 10 \\
\hline & $\begin{array}{c}\text { May-Oct } \\
\text { Chl } a\end{array}$ & $\begin{array}{c}\text { May-Oct } \\
\text { Chl } a\end{array}$ & $\begin{array}{c}\text { May-Oct } \\
\text { Chl } a\end{array}$ & $\begin{array}{c}\text { May-Oct } \\
\text { Chl } a \\
\left(\mathrm{mg} \mathrm{m}^{-3}\right)\end{array}$ & $\begin{array}{c}\text { May-Oct } \\
\text { Chl } a \\
\left(\mathrm{mg} \mathrm{m}^{-3}\right)\end{array}$ & $\begin{array}{c}\text { May-Oct } \\
\text { Chl } a \\
\left(\mathrm{mg} \mathrm{m}^{-3}\right)\end{array}$ \\
\hline Võrtsjärv, 0-3 m & $1982-2013$ & $\uparrow \mathrm{P}<0.01$ & $\uparrow 1997, \mathrm{P}<0.01$ & 33.5 & 49.6 & 41.5 \\
\hline Windermere NB, 0-7 m & $1966-2012$ & $\uparrow \mathrm{P}<0.1$ & $\uparrow 1980, \mathrm{P}<0.05$ & 7.3 & 8.8 & 8.3 \\
\hline Windermere SB, 0-7 m & $1966-2012$ & No & No & & & 12.9 \\
\hline Geneva, $0-20 \mathrm{~m}$ & $1976-2012$ & $\downarrow \mathrm{P}<0.05$ & No & & & 5.6 \\
\hline Maggiore, $0-25 \mathrm{~m}$ & $1984-2013$ & $\downarrow \mathrm{P}<0.01$ & $\downarrow 1997, \mathrm{P}<0.05$ & 4.8 & 3.7 & 4.2 \\
\hline
\end{tabular}

NB, North Basin; SB, South Basin; No, no detected breakpoint. 
temperature was significantly negatively correlated with the main piscivore abundance (Fig. 3).

In Windermere, where commercial fisheries are absent, higher temperature was associated with higher CPUE of the main piscivore (pike) as has also been observed over a longer time scale by Edeline et al. (2016). No direct impact was detected on perch, the main planktivore in this lake, during the present study (Fig. 3), even though over a longer time scale this environmental parameter has been shown to have an important effect on recruitment (Paxton et al., 2004).

\section{Top-down effects in lake ecosystems}

Changes in fish abundance in Lake Geneva may have had strong implications for zooplankton. Long-term changes in whitefish (MPB) abundance were strongly correlated with inter-annual changes in Daphnia abundance (Fig. 3). The negative correlation between Daphnia abundance and whitefish catches suggests whitefish control of cladoceran population which according to Alric et al. (2013) have been under strong top-down pressure during re-oligotrophication of Lake Geneva. Although changes in zooplankton abundance can also be caused by a bottom-up mechanism if changes in phytoplankton species composition alter their palatability and food value for zooplankton (Perga and Lainé, 2013), our results support rather the topdown hypothesis that the effect of the increasing abundance of zooplanktivorous whitefish has contributed to the longterm decrease in Daphnia. Re-oligotrophication has brought about only a slight reduction in phytoplankton biomass in this lake (Tab. 3). As the abundance of Daphnia was strongly negatively correlated with both whitefish and phytoplankton abundance (Fig. 3), the substantial increase in whitefish feeding pressure on zooplankton could presumably reduce the grazing impact of zooplankton on phytoplankton and so enable phytoplankton biomass to increase despite the reduction in TP levels.

As phytoplankton biomass in Maggiore correlated positively with planktivorous coregonids and negatively with the main piscivore (pikeperch), we can draw a general conclusion of strong cascading effects of fisheries on the ecosystem of this lake. In Maggiore, a simultaneous reduction in TP and phytoplankton took place in the
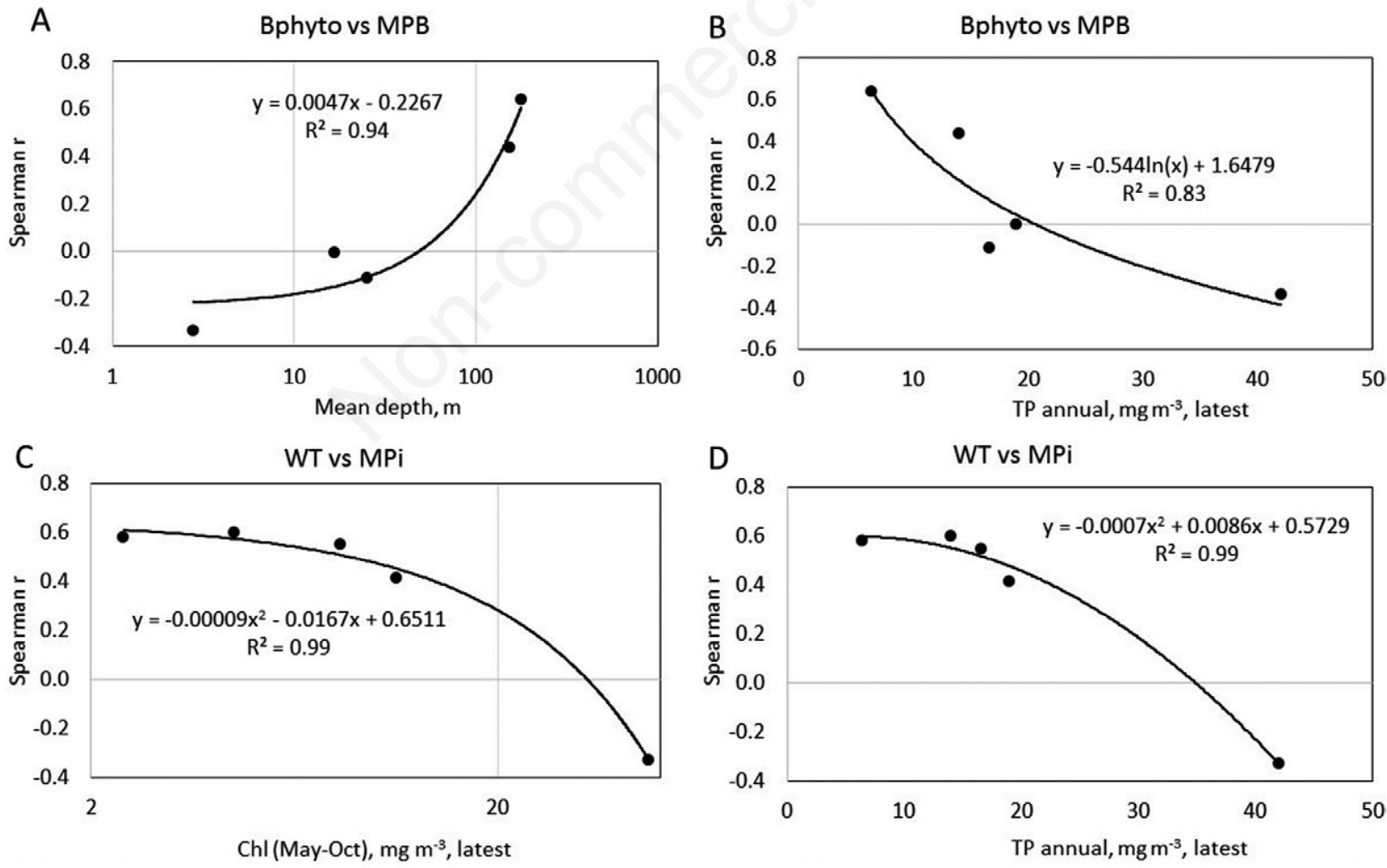

Fig. 4. Changes in the strength of the correlation between phytoplankton and main plankti/benthivorous fish (MPB) along gradients of log lake depth (A) and annual average total phosphorus (TP) concentration of the latest year that our dataset includes, as shown in Tab. 1 (B). Changes in the strength of the correlation between water temperature (WT) and main piscivorous fish (MPi) along gradients of log chlorophyll a (Chla) concentration (C) and TP concentration in the latest year of the time series (D). Each point represents one lake basin. 
1980s-1990s, while in the 2000s occasional high phytoplankton peaks occurred, such as that recorded in summer 2011, caused by an exceptional bloom of Mougeotia sp. (Fig. 5B). Blooms of this taxon are known to occur in the deep peri-alpine oligo-mesotrophic lakes, although the driving factors are still not completely understood (Tapolczai et al., 2015). In Maggiore, the abundance of pikeperch was rather strongly negatively correlated with both whitefish and phytoplankton (Fig. 3), which could reflect a cascading effect of the main piscivore on phytoplankton through the food chain. However, the cascading effect and the phytoplankton response could have been confounded in Lake Maggiore due to the strong nutrient limitation on phytoplankton growth which developed during the re-oligotrophication phase.

In Võrtsjärv, the present correlative analysis and a recent study by Nõges et al. (2016) demonstrated that the main predator (pikeperch) could exert control over phytoplankton, reflected by a significant negative correlation between phytoplankton and pikeperch biomasses (Fig. 3) most likely caused by a cascading top-down effect through the food web. Supporting this, Nõges et al. (2016) found negative correlations between phyto- and zooplankton biomasses in this lake and a shift in zooplankton size structure relative to pikeperch biomass: higher pikeperch abundances were associated with smaller rotifers and larger copepods. In addition, the individual weight of crustacean zooplankton was smaller in years of high abundance of small fish that stimulated ciliate domination over metazooplankton and enhanced the domination of the microbial food web.
In Windermere, phytoplankton was likely primarily bottom-up controlled by phosphorus as no strong correlation with any of its major fish species was detected in this study, although after taking into account the effects of a pathogen outbreak on perch population structure in the 1970s, Edeline et al. (2016) found indications from this longer data set that a pike-dominated intra-guild predation triggered a temperature-controlled trophic cascade passing through pike down to dissolved nutrients.

Across all of our case study lakes, we found a stronger link between phytoplankton and planktivorous fish, and thus a more important cascading top-down effect, in the relatively deeper lakes Geneva and Maggiore (Fig. 4A). The strengths of these connections mean that, for such lakes, careful ecosystem-based fishery management is of utmost importance for maintaining high water quality and related ecosystem services such as recreational values and suitability as drinking water supplies.

Our results also demonstrated that at certain levels of phosphorus loading, increasing water temperature might favour piscivores (Fig. 4D) and thus enhance the potential for a cascading top-down control over phytoplankton. Such an effect could counteract the commonly envisaged impact of climate change supporting elevated phytoplankton development and cyanobacterial blooms (Paerl and Huisman, 2008). Indeed, higher temperatures may be expected to reinforce top-down control in food chains dominated by ectothermic top predators such as fish by increasing consumption rates faster than primary production (Vasseur and McCann, 2005; Ohlberger et al., 2011). Increasing temperature may also lead to different re-
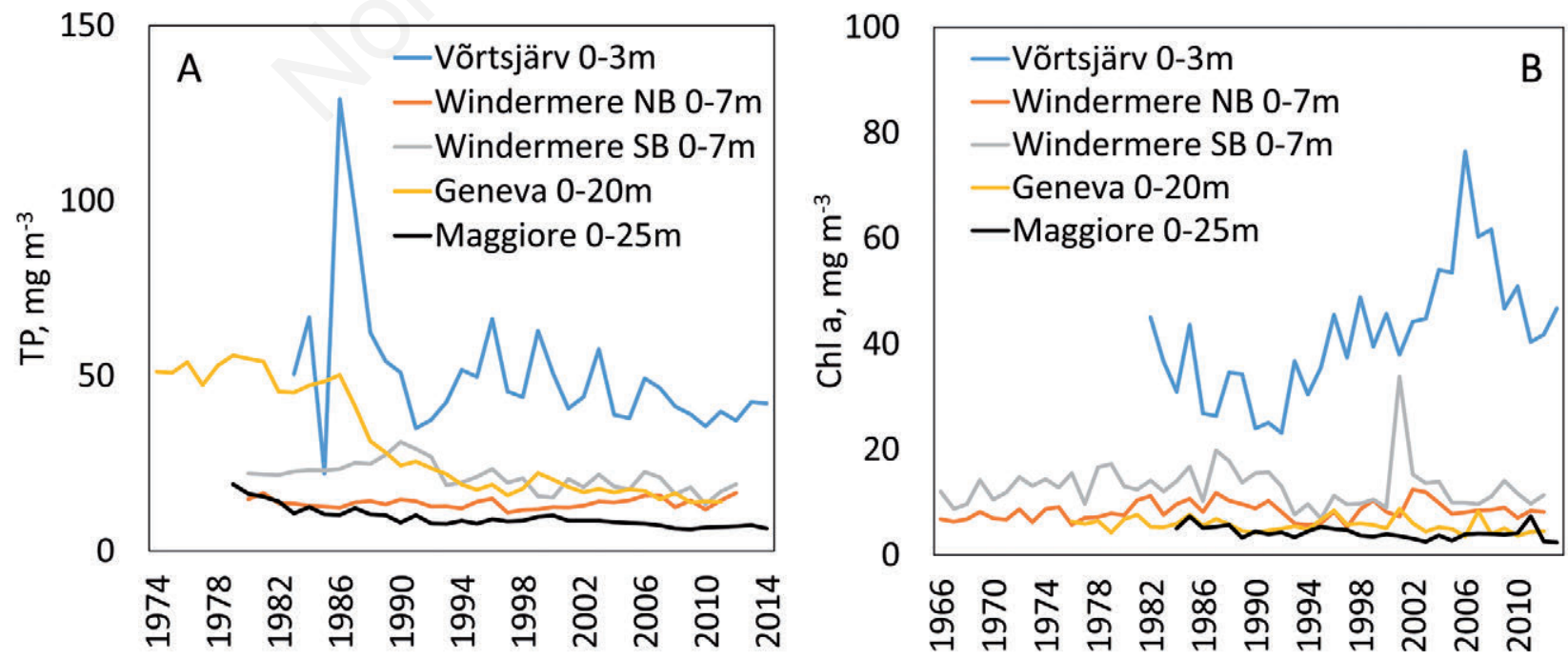

Fig. 5. Time series of annual average total phosphorus (A) and May-October average chlorophyll a concentration (B) in the upper/mixed water column of case study lakes. Windermere NB, North Basin; Windermere SB, South Basin. 
sponses in the same fish species depending on the latitude that determines the starting temperature (Jeppesen et al., 2012). Trophic amplification by climate change - the intensification of trophic interactions and pathways through the food web (Kirby and Beaugrand, 2009; Van Looy et al., 2016) - can result in totally different effects compared to laboratory or microcosm experiments with strongly simplified biotic structure. An increase in fish predation pressure on zooplankton and higher importance of nutrient loading in warm southern lakes was found also by an experimental study undertaken along a latitudinal gradient in Europe (Moss et al., 2004).

These experiments, however, showed also that at higher temperatures, higher zooplankton biomass was required to control phytoplankton which means that the invertebrate grazers did not benefit from the temperature increase as much as the phytoplankton. Similar conclusions were drawn by Malve et al. (2006) in their modelling study. A higher degree of omnivorous feeding by fish and less piscivory in subtropical and tropical lakes than in temperate lakes has been found to limit the success of fish-based biomanipulation methods in warmer climates (Jeppesen et al., 2005). In agreement with these findings, our results showed that at high $\mathrm{P}$ loadings and $\mathrm{Chl} a$ concentrations the correlation between water temperature and piscivores turned negative (Fig. 4 C,D). This finding means that in eutrophic lakes the loss of piscivores in warmer waters might amplify the generally anticipated warming effect of increased frequency of phytoplankton blooms. As a result, this cascading effect also has considerable potential to cause a much greater and wider loss of ecosystem services beyond those directly associated with commercial and recreational fisheries.

\section{CONCLUSIONS}

For the assessment of long-term concurrent effects of fisheries, changing trophic state and changing climate upon lake ecosystems in five European lake basins of differing trophic states (Lake Võrtsjärv, two basins of Windermere, Lake Geneva and Lake Maggiore), the trend analysis, correlations and conceptual food-web analysis led to the following preliminary assumptions which may be used as hypotheses and research questions for further more sophisticated studies:

Decreasing phosphorus concentrations (re-oligotrophication) and increasing water temperatures in all five lake basins have coincided with no changes or only slight decreases in phytoplankton abundance.

Parameters other than phosphorus, including fisheries pressure and the relative abundances of predatory and non-predatory fish species, could explain a significant part of the observed overall variability in fish abundance.

Strong links between phytoplankton and planktivo- rous fish observed in lakes Geneva and Maggiore, could suggest important cascading top-down effect in these relatively deep lakes which makes their careful ecosystembased fisheries management extremely important for maintaining high water quality.

Our analyses indicated that increasing water temperature might favour piscivores at low phosphorus loadings, but suppress them at high phosphorus loadings and might thus either strengthen or weaken the cascading top-down control over phytoplankton with strong implications for water quality.

\section{ACKNOWLEDGMENTS}

The present analysis was funded by MARS project (Managing Aquatic ecosystems and water Resources under multiple Stress) funded by the European Union under the $7^{\text {th }}$ Framework Programme, Theme 6 (Environment including Climate Change) and by institutional research funding IUT 21-02 of the Estonian Ministry of Education and Research.

The Windermere team would like to thank many past and present colleagues, too numerous to name here, for their help in the field and laboratory. They are also indebted to the late John Cooper and Bruce Dobson for allowing use of their records of Arctic charr fishing effort and catches, and to Graeme McKee and colleagues of the Environment Agency for organising and making available the current log book scheme for Arctic charr anglers. They are also grateful to the Freshwater Biological Association for their joint stewardship of the Windermere long-term data and to the Environment Agency for allowing use of their water level data. Underlying components of this work were funded by the Natural Environment Research Council, Environment Agency and United Utilities.

We also thank the Italian-Swiss Commission for the Fishery which provided fish harvest data for Lake Maggiore and the International Commission for the Protection of Italian-Swiss Waters (CIPAIS) for supporting longterm studies on Lake Maggiore. The Lake Geneva team would like to thank the SOERE ${ }^{\circ}$ OLA-IS, INRA Thononles-bains developed by Eco-informatics ORE INRA Team and CIPEL (www.CIPEL.org).

Authors are deeply grateful for the editor and two anonymous reviewers for their constructive suggestions and editing of the manuscript.

\section{REFERENCES}

Alexander TJ, Vonlanthen P, Seehausen O, 2017. Does eutrophication-driven evolution change aquatic ecosystems? Phil. T. R. Soc. B. 372:20160041.

Alric B, Jenny JP, Berthon V, Arnaud F, Pignol C, Reyss JL, Sabatier P, Perga ME, 2013. Local forcings affect lake zoo- 
plankton vulnerability and responses to climate warming. Ecology 94:2767-2780.

Ambrosetti W, Barbanti L, Carrara EA, 2010. Mechanisms of hypolimnion erosion in a deep lake (Lago Maggiore, N. Italy). J. Limnol. 69:3-14.

Anneville O, Lasne E, Guillard J, Eckmann R, Stockwell JD, Gillet C, Yule DL, 2015. Impact of fishing and stocking practices on coregonid diversity. Food Nutr. Sci. 6:1045-1055.

Anneville O, Molinero JC, Souissi S, Balvay G, Gerdeaux D, 2007. Long-term changes in the copepod community of Lake Geneva. J. Plankton Res. 29:49-59.

Anneville O, Pelletier JP, 2000. Recovery of Lake Geneva from eutrophication: quantitative response of phytoplankton. Arch. Hydrobiol. 148:607-624.

Anneville O, Souissi S, Ginot V, Ibanez F, Druart JC, Angeli N, 2002. Temporal mapping of phytoplankton assemblages in Lake Geneva: annual and interannual changes in their patterns of succession. Limnol. Oceanogr. 47:1355-1366.

Anneville O, Souissi S, Molinero JC, Gerdeaux D, 2009. Influences of human activity and climate on the stock-recruitment dynamics of whitefish, Coregonus lavaretus, in Lake Geneva. Fish. Manag. Ecol. 16:492-500.

Anneville O, Vogel C, Lobry J, Guillard J, 2017. Fish communities in the Anthropocene: detecting drivers of changes in the deep peri-alpine Lake Geneva. Inland Waters 7:65-76.

Balushkina EV, Vinberg GG, 1979. [Dependences between mass and length of the body of plankton Crustacea], p. 169-172. In: G.G. Vinberg (ed), [General basics of research in aquatic ecosystems].[Book in Russian]. Nauka, Leningrad.

Baron JS, Poff NL, 2004. Sustaining healthy freshwater ecosystems. Water Resources Update 127:52-58.

Beddington JR, Agnew DJ, Clark CW, 2007. Current problems in the management of marine fisheries. Science 316:1713-1716.

Berg A, Grimaldi E, 1965. [Biologia delle due forme di coregone del Lago Maggiore (Coregonus sp.)].[Article in Italian]. Mem. Ist. Ital. Idrobiol. 18:25-196.

Bunnell DB, Barbiero RP, Ludsin SA, Madenjian CP, Warren GJ, Dolan DM, Brenden TO, Briland R, Gorman OT, He JX, Johengen TH, 2014. Changing ecosystem dynamics in the Laurentian Great Lakes: bottom-up and top-down regulation. BioScience 64:26-39.

Caranhac F, Gerdeaux D, 1998. Analysis of fluctuations in whitefish (Coregonus lavaretus) abundance in Lake Geneva. Arch. Hydrobiol. Spec. Issues Advanc. Limnol. 50:197-206.

Carpenter SR, Kitchell JF, Hodgson JR, 1985. Cascading trophic interactions and lake productivity. BioScience 35:634-639.

Cowx IG, Portocarrero Aya M, 2011. Paradigm shifts in fish conservation: moving to the ecosystem services concept. J. Fish Biol. 79:1663-1680.

Craig JF, 1978. A study of the food and feeding of perch, Perca fluviatilis L., in Windermere. Freshwater Biol. 8:59-68.

Craig JF, Fletcher JM, Winfield IJ, 2015. Insights into percid population and community biology and ecology from a 70year (1943 to 2013) study of perch Perca fluviatilis in Windermere, U.K., p. 148-166. In: P. Couture and G. Pyle (eds), Biology of perch. CRC Press, Boca Raton.

Daskalov GM, Grishin AN, Rodionov S, Mihneva V, 2007. Trophic cascades triggered by overfishing reveal possible mechanisms of ecosystem regime shifts. P. Natl. Acad. Sci. 104:10518-10523.
Dobiesz NE, Hecky RE, Johnson TB, Sarvala J, Dettmers JM, Lehtiniemi M, Rudstam LG, Madenjian CP, Witte F, 2010. Metrics of ecosystem status for large aquatic systems-A global comparison. J. Great Lakes Res. 36:123-138.

Dubois JP, Gillet C, Hilgert N, Balvay G, 2013. The impact of trophic changes over 45 years on the Eurasioan perch, Perca fluviatilis, population of Lake Geneva. Aquat. Living Resour. 21:401-410.

DuFour MR, May CJ, Roseman EF, Ludsin SA, Vandergoot CS, Pritt JJ, Fraker ME, Davis JJ, Tyson JT, Miner JG, Marschall EA, 2015. Portfolio theory as a management tool to guide conservation and restoration of multi-stock fish populations. Ecosphere 6:1-21.

Edeline E, Groth A, Cazelles B, Claessen D, Winfield IJ, Ohlberger J, Asbjørn Vøllestad L, Stenseth NC, Ghil M, 2016. Pathogens trigger top-down climate forcing on ecosystem dynamics. Oecologia 181:519-532.

Everson I, Taabu-Munyaho A, Kayanda R, 2013. Acoustic estimates of commercial fish species in Lake Victoria: Moving towards ecosystem-based fisheries management. Fish. Res. 139:65-75.

Fastner J, Abella S, Litt A, Morabito G, Vörös L, Pálffy K, Straile D, Kümmerlin R, Matthews D, Phillips MG, Chorus I, 2016. Combating cyanobacterial proliferation by avoiding or treating inflows with high $\mathrm{P}$ load - experiences from eight case studies. Aquat. Ecol. 50:367-383.

Fraker ME, Anderson EJ, May CJ, Chen KY, Davis JJ, DeVanna KM, DuFour MR, Marschall EA, Mayer CM, Miner JG, Pangle KL, 2015. Stock-specific advection of larval walleye (Sander vitreus) in western Lake Erie: Implications for larval growth, mixing, and stock discrimination. J. Great Lakes Res. 41:830-845.

Gallardo B, Clavero M, Sànchez MI, Vilà M, 2016. Global ecological impacts of invasive species in aquatic ecosystems. Global Change Biol 22:151-163.

Gerdeaux D, 1988. Fisheries management in an international lake: Lake Geneva, p. 168-181. In: W.L.T. Van Densen, B. Steinmetz and R.H. Hughes (eds), Management of freshwater fisheries: Proceedings of a symposium organized by the European Inland Fisheries Advisory Commission, Göteborg, Sweden, 31 May-3 June 1988. Pudoc, Wageningen.

Gerdeaux D, 2004. The recent restoration of the whitefish fisheries in Lake Geneva: the roles of stocking, reoligotrophication, and climate change. Ann. Zool. Fenn. 41:181-189.

Gerdeaux D, Anneville O, Hefti D, 2006. Fishery changes during re-oligotrophication in 11 peri-alpine Swiss and French lakes over the past 30 years. Acta Oecol. 30:161-167.

Grasshoff K, Ehrhardt M, Kremling K, 1983. Methods of seawater analysis. Verlag Chemie, New York: 419 pp.

Grimaldi E, Numann W, 1972. The future of salmonid communities in the European subalpine lakes. J. Fish. Res. Board Can. 29:931-936.

Gulati RD, Pires LMD, Van Donk E, 2008. Lake restoration studies: failures, bottlenecks and prospects of new ecotechnological measures. Limnologica 38:233-247.

Hessen DO, Kaartvedt S, 2014. Top-down cascades in lakes and oceans: different perspectives but same story? J. Plankton Res. 36:914-924.

Järvalt A, Kangur A, Kangur K, Kangur P, Pihu E, 2004. Fishes and fisheries management, p. 281-295. In: J. Haberman, E. 
Pihu and A. Raukas (eds.) Lake Võrtsjärv. Estonian Encyclopaedia Publishers.

Jeppesen E, Søndergaard M, Jensen JP, Havens K, Anneville O, Carvalho L, Coveney MF, Deneke R, Dokulil M, Foy B, Gerdeaux D, Hampton SE, Kangur K, Köhler J, Körner S, Lammens E, Lauridsen TL, Manca M, Miracle R, Moss B, Nõges P, Persson G, Phillips G, Portielje R, Romo S, Schelske CL, Straile D, Tatrai I, Willén E, Winder M, 2005. Lake responses to reduced nutrient loading - an analysis of contemporary data from 35 European and North American long term studies. Freshwater Biol. 50:1747-1771.

Jeppesen E, Mehner T, Winfield IJ, Kangur K, Sarvala J, Gerdeaux D, Rask M, Malmquist HJ, Holmgren K, Volta P, Romo S, Eckmann R, Sandström A, Blanco S, Kangur A, Stabo HR, Tarvainen M, Ventelä A-M, Søndergaard M, Lauridsen TL, Meerhoff M, 2012. Impacts of climate warming on the long-term dynamics of key fish species in 24 European lakes. Hydrobiologia 694:1-39.

Kirby RR, Beaugrand G, 2009. Trophic amplification of climate warming. P. Roy. Soc. Lond. B-Biol. 276: 4095-4103.

Kolding J, van Zwieten PA, 2014. Sustainable fishing of inland waters. J. Limnol. 73:132-148.

Kundzewicz ZW, Robson AJ, 2004. Change detection in hydrological records - a review of the methodology. Hydrol. Sci. J. 49:7-19.

Laine L, Perga ME, 2015. The zooplankton of Lake Geneva, p. 127-136. In: Rapport de la Commission International pour la Protection des Eaux du Léman contre la pollution, Campagne 2014.

Le Cren ED, 1992. Exceptionally big individual perch (Perca fluviatilis) and their growth. J. Fish Biol. 40:599-625.

Le Cren ED, 2001. The Windermere perch and pike project. Freshwater Forum 15: 3-34.

Li ZL, Xu ZX, Li JY, Li ZJ, 2008. Shift trend and step changes for runoff time series in the Shiyang River basin, northwest China. Hydrol. Process. 22: 4639-4646.

Lorenzen CJ, 1967. Determination of chlorophyll and pheo-pigments: spectrophotometric equations. Limnol. Oceanogr. 12:2:343-346.

Lund JWG, Kipling C, Le Cren ED, 1958. The inverted microscope method of estimating algal numbers and the statistical basis of estimations by counting. Hydrobiologia 11:143-170.

Mackereth FGH, Heron J, Talling JF, 1978. Water analysis: some revised methods for limnologists. Freshwater Biological Association: $120 \mathrm{pp}$.

Malve O, Laine M, Haario H, Kirkkala T, Sarvala J, 2007. Bayesian modelling of algal mass occurrences - using adaptive MCMC methods with a lake water quality model. Environ. Modell. Softw. 22:966-977.

Manca M, Ruggiu D, 1998. Consequences of pelagic food web changes during a long-term lake oligotrophication process. Limnol. Oceanogr. 43:1368-1373.

Manca M, Torretta B, Comoli P, Amsinck SL, Jeppesen E, 2007. Major changes in trophic dynamics in large, deep sub-alpine Lake Maggiore from 1940s to 2002: a high resolution comparative paleo-neolimnological study. Freshwater Biol. 52:2256-2269.

Marchetto A, Lami A, Musazzi S, Massaferro J, Langone L, Guilizzoni P, 2004. Lake Maggiore (N. Italy) trophic history: fossil diatom, plant pigments, and chironomids, and com- parison with long-term limnological data. Quatern. Int. 113:97-110.

Massol F, David P, Gerdeaux D, Jarne P, 2007. The influence of trophic status and large-scale climatic change on the structure of fish communities in Perialpine lakes. J. Anim. Ecol. 76:538-551.

McCormack JC, 1970. Observations on the food of perch (Perca fluviatilis L.) in Windermere. J. Anim. Ecol. 39:255-267.

McIntyre PB, Jones LE, Flecker AS, Vanni MJ, 2007. Fish extinctions alter nutrient recycling in tropical freshwaters. P. Natl. Acad. Sci. USA 104:4461-4466.

Molinero JC, Anneville O, Souissi S, Lainé L, Gerdeaux D, 2007. Decadal changes in water temperature and ecological time-series in Lake Geneva, Europe - relationship to subtropical Atlantic climate variability. Climate Res. 34:15-23.

Monod R, Blanc P, Corvi C, 1984. [Le régime thermique du Léman], p. 75-88. In: CIPEL (ed). [Le Léman synthèse 1957-1982].[Book in French]. CIPEL, Lausanne.

Moss B, Stephen D, Balayla DM, Bécares E, Collings SE, Fernández-Aláez C, Fernández-Aláez M, Ferriol C, García P, Gomá J, Gyllström M, Hansson LA, Hietala J, Kairesalo T, Miracle MR, Romo S, Rueda J, Russell V, Ståhl-Delbanco A, Svensson M, Vakkilainen K, Valentín M, Van de Bund WJ, Van Donk E, Vicente E, Villena MJ, 2004. Continentalscale patterns of nutrient and fish effects on shallow lakes: synthesis of a pan-European mesocosm experiment. Freshwater Biol. 49:1633-1649.

Müller R, 1992. Trophic state and its implications for natural reproduction of salmonid fish. Hydrobiologia 243/244:261-268.

Nõges P, Nõges T, 2012. Võrtsjärv Lake in Estonia, p. 850-861. In: L. Bengtsson, R.W. Herschy and R.W. Fairbridge (eds.) Encyclopedia of lakes and reservoirs. Springer, Dordrecht.

Nõges P, Nõges T, 2014. Weak trends in ice phenology of Estonian large lakes despite significant warming trends. Hydrobiologia 731:5-18.

Nõges P, Nõges T, Laas A, 2010. Climate-related changes of phytoplankton seasonality in large shallow Lake Võrtsjärv, Estonia. Aquat. Ecosys. Health 13:154-163.

Nõges T, Järvalt A, Haberman J, Zingel P, Nõges P, 2016. Is fish able to regulate filamentous blue-green dominated phytoplankton? Hydrobiologia 780:59-69.

Obertegger U, Manca M, 2011. Response of rotifer functional groups to changing trophic state and crustacean community. J. Limnol. 70:231-238.

Ohlberger J, Edeline E, Vøllestad LA, Stenseth NC, Claessen D, 2011. Temperature driven regime shifts in the dynamics of size-structured populations. Am. Nat. 177:211-223.

Paerl HW, Huisman J, 2008. Blooms like it hot. Science 320:57-58.

Parker JE, Maberly SC, 2000. Biological response to lake remediation by phosphate stripping: control of Cladophora. Freshwater Biol. 44:303-309.

Paxton CGM, Winfield IJ, Fletcher JM, George DG, Hewitt DP, 2004. Biotic and abiotic influences on the recruitment of perch (Perca fluviatilis) in Windermere. U.K. J. Fish Biol. 65:1622-1642.

Paxton CGM, Winfield IJ, Fletcher JM, George DG, Hewitt DP, 2009. Investigation of first year biotic and abiotic influences on the recruitment of pike Esox lucius over 48 years in Windermere. U.K. J. Fish Biol. 74:2279-2298. 
Perga ME, Lainé L, 2013. [Zooplancton du Léman], p. 102-112. In: [Rapp. Comm. Int. Prot. Eaux Léman contre pollution (CIPEL), Campagne 2012].[Report in French].

Persson L, Van Leeuwen A, De Roos AM, 2014. The ecological foundation for ecosystem-based management of fisheries: mechanistic linkages between the individual-, population-, and community-level dynamics. ICES J. Mar. Sci. 71:1-13.

Pikitch EK, Santora C, Babcock EA, Bakun A, Bonfil R, Conover DO, Dayton P, Doukakis P, Fluharty D, Heneman B, Houde ED, Link J, Livingston PA, Mangel M, McAllister MK, Pope J, Sainsbury K, 2004. Ecosystem-based fishery management. Science 305:346-347.

Pine III WE, Martell SJ, Walters CJ, Kitchell JF, 2009. Counterintuitive responses of fish populations to management actions: some common causes and implications for predictions based on ecosystem modeling. Fisheries 34:165-180.

Salomon AK, Shears NT, Langlois TJ, Babcock RC, 2008. Cascading effects of fishing can alter carbon flow through a temperate coastal ecosystem. Ecol. Appl. 18:1874-1887.

Shapiro J, Wright DI, 1984. Lake restoration by biomanipulation: Round Lake, Minnesota, the first two years. Freshwater Biol. 14:371-383.

Sharma S, Gray DK, Read JS, O'Reilly CM, Schneider P, Qudrat A, Gries C, Stefanoff S, Hampton SE, Hook S, Lenters JD, Livingstone DM, McIntyre PB, Adrian R, Allan MG, Anneville O, Arvola L, Austin J, Bailey J, Baron JS, Brookes J, Chen Y, Daly R, Dokulil M, Dong B, Ewing K, de Eyto E, Hamilton D, Havens K, Haydon S, Hetzenauer $\mathrm{H}$, Heneberry J, Hetherington AL, Higgins SN, Hixson E, Izmest'eva LR, Jones BM, Kangur K, Kasprzak P, Köster O, Kraemer BM, Kumagai M, Kuusisto E, Leshkevich G, May L, MacIntyre S, Müller-Navarra D, Naumenko M, Noges P, Noges T, Niederhauser P, North RP, Paterson AM, Plisnier PD, Rigosi A, Rimmer A, Rogora M, Rudstam L, Rusak JA, Salmaso N, Samal NR, Schindler DE, Schladow G, Schmidt SR, Schultz T, Silow EA, Straile D, Teubner K, Verburg P, Voutilainen A, Watkinson A, Weyhenmeyer GA, Williamson CE, Woo KH, 2015. A global database of lake surface temperatures collected by in situ and satellite methods from 1985-2009. Sci. Data 2:150008.

Schindler DW, 2006. Recent advances in the understanding and management of eutrophication. Limnol. Oceanogr. 51:356-363.

Søndergaard M, Jeppesen E, Lauridsen TL, Skov C, Van Nes EH, Roijackers R, Lammens E, Portielje ROB, 2007. Lake restoration: successes, failures and long-term effects. J. Appl. Ecol. 44:1095-1105.

Strickland JDH, Parsons TR, 1968. A practical handbook of sea water analysis. Bull. Fish. Res. Board Can.: 311 pp.

Suuronen P, Bartley DM, 2014. Challenges in managing inland fisheries - using the ecosystem approach. Boreal Environ. Res. 19:245-256.

Talling JF, 1974. Photosynthetic pigments. General outline of spectrophotometric methods; specific procedures, p. 22-26. In: R.A. Vollenweider (ed.) A Manual on methods for measuring primary productivity in aquatic environments. Blackwell Scientific Publications, Oxford.

Tapolczai K, Anneville O, Padisák J, Salmaso N, Morabito G, Zohary T, Tadonléké RD, Rimet F, 2015. Occurrence and mass development of Mougeotia spp. (Zygnemataceae) in large, deep lakes. Hydrobiologia 745:17-29.

Trochine C, Brucet S, Argillier C, Arranz I, Beklioglu M, Benejam L, Ferreira T, Hesthagen T, Holmgren K, Jeppesen E, Kelly F, Krause T, Rask M, Volta P, Winfield IJ, Mehner T, 2017. Non-native fish occurrence and biomass in 1943 Western Palearctic lakes and reservoirs and their abiotic and biotic correlates. Ecosystems, doi: 10.1007/s10021-017-0156-6

Valderrama JC, 1981. The simultaneous analysis of total nitrogen and total phosphorus in natural waters. Mar. Chem. 10:109-122.

Van Looy K, Floury M, Ferréol M, Prieto-Montes M, Souchon Y, 2016. Long-term changes in temperate stream invertebrate communities reveal a synchronous trophic amplification at the turn of the millennium. Sci. Total Environ 565:481-488.

Vasseur DA, McCann KS, 2005. A mechanistic approach for modelling temperature-dependent consumer-resource dynamics. Am. Nat. 166:184-198.

Volta P, 2000. [Il regime alimentare delle diverse forme di coregone (Coregonus spp.) del Lago Maggiore alla luce della recente evoluzione trofica ambientale].[Master Thesis in Italian]. Università dell'Insubria, Varese.

Volta P, Oggioni A, Bettinetti R, Jeppesen E, 2011. Assessing lake typologies and indicator fish species for Italian natural lakes using past fish richness and assemblages. Hydrobiologia 671:227-240.

Vonlanthen P, Bittner D, Hudson AG, Young KA, Müller R, Lundsgaard-Hansen B, Roy D, Di Piazza S, Largiadèr CR, Seehausen O, 2012. Eutrophication causes speciation reversal in whitefish adaptive radiations. Nature 482:357-362.

Winfield IJ, Fletcher JM, James JB, 2008a. The Arctic charr (Salvelinus alpinus) populations of Windermere, U.K.: population trends associated with eutrophication, climate change and increased abundance of roach (Rutilus rutilus). Environ. Biol. Fish 83:25-35.

Winfield IJ, James JB, Fletcher JM, 2008b. Northern pike (Esox lucius) in a warming lake: changes in population size and individual condition in relation to prey abundance. Hydrobiologia 601:29-40.

Yurk JJ, Ney JJ, 1989. Phosphorus-fish community biomass relationships in southern Appalachian Reservoirs: Can lakes be too clean for fish? Lake Reserv. Manage. 5:83-90. 